\title{
Budaya Kekerasan dalam Media Elektronik Ditinjau dari Sudut Pandang Etika Kristen
}

\author{
Novita Indriani Rorong ${ }^{1}$, Dicky Dominggus ${ }^{2}$ \\ ${ }^{1}$ Sekolah Tinggi Teologi Iman Jakarta, Indonesia \\ ${ }^{2}$ Sekolah Tinggi Injil Bhakti Caraka Batam, Indonesia \\ Email: novitarorong.nir@gmail.com
}

\begin{tabular}{|l|l|l|}
\hline Diterima: 29 Maret 2020 & Direvisi: 23 April 2020 & Disetujui: 11 Juni 2020 \\
\hline
\end{tabular}

\begin{abstract}
Abstrak
Kekerasan telah menjadi sebuah tindakan yang lumrah dan biasa terjadi dalam kehidupan manusia. Kekerasan disebabkan oleh banyak faktor, namun penulis menyoroti bahwa media elektronik yang menyuguhkan film, game, dan musik yang mengandung unsur kekerasan telah memberikan kontribusi besar untuk menjadi salah satu penyebab terjadinya kekerasan dalam kehidupan manusia. Artikel ini merupakan sebuah studi untuk membangun pedoman etis sebagai pegangan hidup setiap orang Kristen. Pedoman etis ini merupakan sebuah solusi untuk menjawab permasalahan mengenai budaya kekerasan dalam media elektronik yang terjadi dalam kehidupan manusia di era globalisasi dewasa ini. Artikel ini merupakan penelitian kualitatif dengan pendekatan studi pustaka. Adapun hasil dari penelitian ini adalah budaya kekerasan dapat diatasi dengan menerapkan prinsip kasih sebagai nilai tertinggi di dalam kehidupan seseorang. Selain itu, setiap orang perlu mengembangkan sikap moral dalam kehidupannya seperti menghargai manusia sebagai ciptaan Allah yang serupa dan segambar dengan Allah, memiliki kasih terhadap sesama, dan memiliki pengendalian diri dalam segala hal.
\end{abstract}

Kata-Kata Kunci: Budaya kekerasan; Etika Kristen; Media elektronik. 


\section{Abstract}

The violences are caused by many factors but these writers highlight that electronic media serving films, games and music scenes or lyrics that incite violence have influenced greatly to be one cause of the violence in human life. This article, we discuss a study intended to develop ethical guidelines for any Christian. Ethical guidelines we discuss here are solution to the problems about the culture of violence in electronic media that commonly happen in our digital life in a globalized world today. This article is a qualitative research with a literature study approach. The result of this research is that culture of violence can be overcome by applying the principle of love as the highest value in one's life. In addition, everyone needs to develop moral attitudes in his life such as respecting humanity as God's creation that is similar and likened to God, having love for others, and having self-control in everything.

Keywords: Culture of violence; Christian ethics; Electronic media.

\section{Pendahuluan}

Sebuah pepatah kuno dalam bahasa Latin yaitu Homo homini lupus est memiliki arti bahwa manusia adalah serigala bagi manusia yang lain. Dengan kata lain, demi memertahankan keberadaan dirinya, manusia rela memakan sesamanya sendiri dengan melakukan kekerasan yang menyengsarakan. ${ }^{1} \mathrm{Hal}$ ini terbukti dengan adanya peningkatan angka kekerasan, salah satu contohnya kekerasan terhadap anak di Indonesia. Linda Amalia Sari Gumelar sebagai Menteri Pemberdayaan Perempuan dan Perlindungan Anak memaparkan bahwa:

Data dari Komisi Perlindungan Anak Indonesia (KPAI) tahun (KPAI) yang mencatat sebanyak 4.294 kasus kekerasan pada anak dilakukan oleh keluarga dan pengasuh (2011-2016). sedangkan hasil pemantauan Komisi Perlindungan Anak Indonesia (KPAI) melalui survei terhadap 1.026 siswa SD, SMP, dan SMU di 9 provinsi, menemukan anak sebagai pelaku kekerasan mencapai $78,3 \%$. Selain itu kekerasan anak di masyarakat sebesar 80,2\%, dan kekerasan anak di sekolah 87,6\%, serta kekerasan anak dalam keluarga tercatat $91 \% .^{2}$

Kekerasan dalam kehidupan manusia semakin mengalami peningkatan yang disebabkan oleh media elektronik menyajikan banyak pilihan yang mengandung unsur kekerasan, sehingga kekerasan menjadi menu pilihan utama

${ }^{1}$ Surip Stanislaus, Semerbak Alkitab 3 Mematahkan Siklus Kekerasan (Yogyakarta: Kanisius, 2007), 1.

2 Scholastica Gerintya, "73,7 Persen Anak Indonesia Mengalami Kekerasan Di Rumahnya Sendiri - Tirto.ID." 
dalam media elektronik. Sebagai contohnya, jika memerhatikan isi media yang ditampilkan untuk publik, tidak sedikit tayangan yang mengandung unsur kekerasan menjadi konsumsi khalayak. Tayangan yang mengandung unsur kekerasan ini telah menjadi tayangan yang mendominasi, mulai dari segmen orang dewasa sampai anak-anak. Sinetron-sinetron di televisi kerap memertontonkan adegan perkelahian, tamparan, cacian dan hinaan dalam setiap segmen-nya bahkan dalam film anak-anak pun seperti film kartun, film serial tidak luput dari adegan-adegan kekerasan. Selain itu, games-games kekerasan yang seringkali membuat banyak anak-anak kecanduan dan bahkan tidak hanya anak-anak namun juga kaum bapak, dan dari berbagai kalangan bisa kecanduan games. Selain itu juga, berita-berita kriminal seperti patroli, sidik, buser, sergap, dan jejak kasus menjadi program yang mengekspos tindak kekerasan.

Hampir setiap hari dijumpai tayangan di media elektronik segala bentuk kekerasan yang disajikan seperti maraknya kejahatan, korupsi, tindakan anarkhis, main hakim sendiri, maraknya budaya kekerasan, radikalisme, intoleransi, dan sebagainya. Semua itu akan berdampak buruk, yaitu terkikisnya nilai-nilai luhur karena semakin kuatnya pengaruh budaya media (media culture) sebagai pembentuk nilai-nilai para orang muda. ${ }^{3}$

Masalah dalam media elektronik yang mengandung unsur kekerasan adalah ketika tayangan kekerasan tersebut sudah menjadi realita sosial di tengah masyarakat dan menjadikan kekerasan sesuatu yang biasa saja atau lumrah. Keadaan ini membuat manusia membutuhkan kekerasan seperti halnya membutuhkan seks, makanan, dan obat-obatan, yang merupakan kebutuhan dasar dalam kehidupan manusia.

Sebagai contoh kasus seorang anak SD di Cinere, Depok, umur 12 tahun, kelas 6 SD melakukan penusukan pada teman sekolahnya selesai bermain game berbau kekerasan. Meskipun fiksi tidak sama dengan realita, tetapi fiksi yang telah dikemas oleh media dapat menimbulkan anggapan-anggapan realita dan menyuguhkan ide-ide baru yang sebelumnya tidak terpikirkan di dalam realita kehidupan sosial. Sangatlah ironi, jika seseorang memeroleh ide membunuh karena pengaruh menonton tayangan-tayangan kekerasan di media atau memainkan games-games yang mengandung unsur kekerasan. ${ }^{4}$

\footnotetext{
${ }^{3}$ Kalis Stevanus, "Tujuh Kebajikan Utama Untuk Membangun Karakter Kristiani Anak," BIA': Jurnal Teologi dan Pendidikan Kristen Kontekstual 1, no. 1 (June 2018): 80.

${ }^{4}$ Ira Oemar, "Anak SD Melakukan Pembunuhan Berencana Terhadap Temannya Kompasiana.Com.”
} 
Hal itu terjadi karena tayangan kekerasan dalam media elektronik dibungkus secara dramatis sehingga menimbulkan sensasi kenikmatan tersendiri ketika menonton. Dengan cara ini, media sangat mudah untuk memengaruhi penonton. Secara sadar penonton dapat membedakan antara kondisi riil dan fiktif, akan tetapi jika penonton terus menerus mendapat terpaan media berupa kekerasan maka kondisi ini dapat melahirkan desensitisasi, yaitu penumpulan kepekaan terhadap kekerasan, yang pada gilirannya akan membuat manusia berpotensi untuk melakukan tindakan kekerasan.

Dari sisi pengaruhnya, tindakan kekerasan dapat meningkatkan agresivitas pada anak, remaja dan orang dewasa.

Sebuah meta-analisis dari penelitian tersebut menunjukan bahwa semakin tinggi frekuensi kontak terhadap kekerasan dalam media, semakin kuat pula kemungkinan seseorang untuk berperilaku secara agresif. Akan tetapi, ketika seseorang mengurangi waktu yang biasa digunakannya untuk menyaksikan tayangan yang mengandung unsur kekerasan dalam media, maka tingkat agresivitasnya akan menurun. ${ }^{5}$

Berdasarkan penelitian tersebut tersebut dapat disimpulkan bahwa kekerasan yang termuat dalam televisi melalui film, game, dan musik menunjukan bukti yang jelas bahwa kekerasan pada media meningkatkan kecenderungan perilaku agresif dan keras, baik dalam jangka pendek maupun jangka panjang.

Oleh karena itu, masalah budaya kekerasan dalam media elektronik secara substansial, layak untuk dicarikan pemecahan masalahnya. Bagaimana sikap orang percaya menempatkan masalah ini dan meninjaunya dari sudut pandang etika Kristen merupakan sebuah solusi yang tepat untuk menjawab permasalahan tersebut.

\section{Metode Penelitian}

Penelitian ini menggunakan penelitian metode kualitatif dengan pendekatan studi pustaka. Studi pustaka merupakan teknik pengumpulan data dengan mengadakan studi penelaah buku-buku, literatur, catatan, dan laporan yang berhubungan dengan masalah yang dibahas. ${ }^{6}$ Pembahasan pada artikel ini menyoroti budaya kekerasan dalam media Elektronik ditinjau dari sudut

${ }^{5}$ Carole Wade and Carol Tavris, Psikologi (Jakarta: Erlangga, 2007), 275.

${ }^{6}$ Andreas B Subagyo, Kualitatif: Termasuk Riset Teologi Dan Keagamaan (Bandung: Yayasan Kalam Hidup, 2004). 
pandang etika Kristen. Untuk itu, budaya kekerasan akan ditinjau dari Perjanjian Lama dan Perjanjian Baru dengan memerhatikan prinsip etika didalamnya.

\section{Pembahasan dan Hasil}

Kekerasan secara umum dipahami sebagai tindakan fisik yang mengakibatkan individu atau sekelompok orang terluka, bahkan sampai meninggal dunia. ${ }^{7}$ Di sisi lain, kekerasan juga merupakan penggunaan kekuatan fisik dan kekuatan, terhadap diri sendiri yang mengakibatkan memar/trauma. ${ }^{8}$ Berdasarkan definisi yang ada kekerasan merupakan tindakan yang mengakibatkan luka secara fisik maupun psikologis. ${ }^{9}$

Kekerasan dalam bentuk fisik yang dimaksudkan disini merupakan tindakan fisik mengakibatkan orang lain mengalami luka fisik, dimulai dari intensitas kecil berupa memukul, menendang, menampar, meludahi, menikam, menembak, dan mendorong, melukai dengan senjata, hingga intensitas besar berupa pembunuhan. Sedangkan kekerasan secara verbal adalah tindakan yang diungkapkan berupa menghina, membentak, memarahi, menakut-nakuti, mengeluarkan kata-kata yang tidak pantas, melecehkan dan mengancam yang mengakibatkan orang lain mengalami luka secara batin, emosional, dan mental. Dengan demikian, kekerasan dalam bentuk fisik maupun verbal, kedua-duanya termasuk perilaku yang menyimpang dari norma masyarakat ${ }^{10}$ dan undangundang $^{11}$ yang berlaku.

\footnotetext{
${ }^{7}$ Yorita Febry Lismanda, Mutiara Sari Dewi, and Ika Anggraheni, "Media Elektronik Dan Pengawasan Orang Tua Sebagai Pendidikan Anti Kekerasan AUD Dalam Perspektif Psikologi," SELING: Jurnal Program Studi PGRA 1, no. 2 (2015): 110.

${ }^{8}$ Thathit Manon Andini, "Identifikasi Kejadian Kekerasan Pada Anak Di Kota Malang," Jurnal Perempuan dan Anak 2, no. 1 (April 21, 2019): 15.

${ }^{9}$ Firman Panjaitan, "Kekerasan Terhadap Istri Dalam Lingkup Domestik (Suatu Tinjauan Etis Kristiani Tentang Kekerasan Terhadap Keluarga)," FIDEI: Jurnal Teologi Sistematika dan Praktika 1, no. 1 (2018): 46.

${ }^{10}$ J Sudarminta, Etika Umum: Kajian Tentang Beberapa Masalah Pokok Dan Teori Etika Normatif (Yogyakarta: Kanisius, 2013), 17.

${ }^{11}$ Kitab Undang-Undang Hukum Pidana (KUHP), mengenai ancaman kekerasan diatur dalam Pasal 368 ayat (1) KUHP yang berbunyi: "Barang siapa dengan maksud untuk menguntungkan diri sendiri atau orang lain secara melawan hukum, memaksa seorang dengan kekerasan atau ancaman kekerasan untuk memberikan barang, yang seluruhnya atau sebagian adalah kepunyaan orang lain, atau supaya membuat hutang maupun menghapuskan piutang, diancam karena pemerasan, memperoleh tindak pidana penjara paling lama sembilan tahun. Jika ancaman tersebut melalui media elektronik, pelaku pengancaman dapat dikenakan pidana berdasarkan Pasal 29 Pasal 45 ayat (3) UU No.11 Tahun 2008 tentang Informasi dan Transaksi Elektronik (UU ITE). S H Solahuddin, Kitab Undang-Undang Hukum Pidana, Acara Pidana, Dan Perdata (Jakarta: Visi Media, 2008), 82.
} 
Budaya berasal dari Bahasa Sansekerta yaitu buddhayah, yang merupakan bentuk jamak dari buddhi dan diartikan sebagai hal-hal yang berkaitan dengan budi dan akal manusia."12 Pengertian tersebut menunjukan bahwa kebudayaan dimulai dari akal budi atau pengetahuan. Pengetahuan ini, membentuk pandangan hidup sekelompok orang dalam bentuk perilaku, kepercayaan, nilai, dan simbol-simbol yang diterima tanpa sadar, yang diwariskan melalui proses komunikasi dan peniruan dari satu generasi ke generasi berikut. ${ }^{13}$ Hal ini menjadi suatu cara hidup yang berkembang dan dimiliki bersama oleh sebuah kelompok, dan menjadi sebuah kebiasaan yang sukar diubah. ${ }^{14}$

Budaya dan media komunikasi ${ }^{15}$ tidak dapat dipisahkan satu dengan yang lain, karena kebudayaan menentukan apa dan bagaimana komunikasi itu berlangsung. Pada dasarnya, komunikasi bersifat langsung dan tidak langsung atau termediasi. ${ }^{16}$ Kebudayaan dalam kaitannya dengan media menentukan bagaimana pesan-pesan ditangkap dan makna-makna disampaikan. Dewasa ini, media komunikasi telah berhasil membuat kekerasan menjadi budaya yang berkembang dalam kehidupan manusia. Kekerasan dianggap hal yang biasa karena telah menjadi konsumsi pikiran dan termanifestasi dalam tindakan sehari-hari. ${ }^{17}$ Seperti yang diungkapkan oleh seorang pemikir kajian budaya dari Inggris bernama Raymond Williams bahwa kekerasan disebut budaya ketika "kekerasan atau violence, ketakutan atau horor dan teror berkonspirasi membentuk perilaku yang menyimpang dan menjadi praksis kehidupan masyarakat." $" 18$

${ }^{12}$ R M Drie S Brotosudarmo, Etika Kristen Untuk Perguruan Tinggi (Yogyakarta: ANDI, 2007), 114.

${ }^{13}$ Alo Liliweri, Makna Komunikasi Dalam Komunikasi Antarbudaya (Yogyakarta: PT. LKiS Pelangi Aksara, 2007).

14 Nurdien Harry Kistanto, "Tentang Konsep Kebudayaan," Sabda: Jurnal Kajian Kebudayaan 10, no. 2 (2015).

${ }^{15}$ Lukas Batmomolin and Fransisca Hermawan, Budaya Media: Bagaimana Pesona Media Elektronik Memperdaya Anda (Flores: Nusa Indah, 2003).

${ }^{16}$ Komunikasi yang bersifat tidak langsung atau termediasi adalah komunikasi yang berlangsung lewat medium atau sarana komunikasi massa, seperti radio, televisi, koran dan alatalat elektronik yang lainnya. Prayanto Widyo Harsanto, "Metamorfosis Kebudayaan (Sebuah Tinjauan Media Televisi Dan Budaya Kekerasan)," Nirmana 11, no. 1 (2009): 11-18.

${ }^{17}$ Batmomolin and Hermawan, Budaya Media: Bagaimana Pesona Media Elektronik Memperdaya Anda.

${ }^{18}$ Ida Ayu Made Gayatri, "Kekerasan Dan Budaya Kekerasan." 


\section{Dampak Budaya Kekerasan}

Budaya kekerasan yang dipicu melalui media elektronik ini memberikan dampak negatif ke berbagai aspek dalam kehidupan manusia diantaranya terhadap psikologi manusia yang terdiri dari kognitif, afektif dan behaviour manusia. Selain itu, berdampak juga terhadap kehidupan sosial manusia baik di kalangan anak, remaja maupun dewasa. ${ }^{19}$

Dampaknya terhadap kognitif manusia adalah terganggunya fungsi otak depan yang berfungsi untuk menyaring informasi yang masuk melalui pancaindera. Dalam sistem kerja otak, pada saat menonton tayangan kekerasan maka informasi masuk dan terekam dalam otak tanpa tersaring oleh penonton. ${ }^{20}$ Penonton dijejali oleh segudang informasi tentang kekerasan tanpa mengadakan reaksi terhadap informasi tersebut dan reaksi dapat timbul kemudian tanpa disadari. Pengaruh lainnya adalah, sesuai dengan yang dikatakan Alfin Toffler, bahwa rangsangan yang terus menerus pada indera melumpuhkan kemampuan otak untuk berpikir sehingga akhirnya akan menumpulkan rasio berpikir. Ketika fungsi otak depan ditekan untuk menyaring informasi yang masuk melalui indera penglihatan dan pendengaran, maka dengan mudah seseorang akan menyerap dan mengasimilasi hal-hal buruk yang ditontonnya di televisi. ${ }^{21}$

Dampaknya terhadap afektif manusia adalah bangkitnya rasa marah setelah diterpa tayangan kekerasan. Bangkitnya rasa marah ini, dalam istilah teori Arousal, ditransfer pada kemarahan yang sesungguhnya bahkan mengintensifkannya hingga menambah kecenderungan perilaku agresif. 22 Selain itu, penonton yang terus menerus mendapat terpaan media berupa kekerasan maka kondisi ini dapat melahirkan desensitisasi, yaitu penumpulan kepekaan terhadap kekerasan, yang pada gilirannya akan membuat manusia berpotensi untuk melakukan tindakan kekerasan.23

Dampaknya terhadap behaviour manusia adalah seseorang yang akrab dengan media yang mengandung unsur kekerasan dapat menyebabkan

${ }^{19}$ Hendro Hariyanto Siburian and Arif Wicaksono, "Makna Belajar Dalam Perjanjian

Lama Dan Implementasinya Bagi PAK Masa Kini," FIDEI: Jurnal Teologi Sistematika dan

Praktika 2, no. 2 (2019): 212-213.

${ }^{20}$ Jerry Mander, Four Arguments for the Elimination of Television (New York: Quill New York, 1997).

${ }^{21}$ Ibid.

${ }^{22}$ Jennings Bryant and Dolf Zillmann, "Effect of Intensification of Annoyance through Unrelated Residual Excitation on Substantially Delayed Hostile Behavior," Journal of Experimental Social Psychology 15, no. 5 (1979): 470.

${ }^{23}$ L Rowell Huesmann and Lucyna Kirwil, Why Observing Violence Increases the Risk of Violent Behavior by the Observer. (Cambridge: Cambridge University Press, 2007). 
perkembangan jiwanya terganggu. Para pakar psikologi berpendapat bahwa hal ini dapat meningkatkan perilaku agresif dan bahkan berpotensi pada gangguan jiwa yang termasuk ke dalam golongan gangguan kepribadian dengan pola agresif. Ciri-ciri orang seperti ini adalah mudah tersinggung dan destruktif. Selain itu, ide-ide agresif yang ditawarkan oleh media akan tertanam dalam memorinya dan ide tersebut akan aktif ketika mereka berada dalam keadaan marah atau tertekan. ${ }^{24}$

Dampaknya terhadap kehidupan sosial anak-anak adalah mereka akan mudah meniru adegan kekerasan. Dalam proses peniruan ini, anak akan menyimpan gambaran-gambaran kekerasan ke dalam memorinya dalam bentuk imajinasi atau lambang secara verbal. Hal ini akan menjadi ingatan dan hasil ingatan tersebut akan terwujud menjadi perilaku. Gambaran kekerasan yang sudah tersimpan dalam imajinasi dinyatakan kembali sehingga dapat menghasilkan perilaku agresif. ${ }^{25}$ Berkowitz mengatakan bahwa "ide-ide agresif yang ditawarkan tayangan kekerasan dapat tertanam dalam memori anakanak." ${ }^{26}$ Selain itu, anak menjadi tidak peka pada penderitaan orang lain. Dampak negatif kekerasan tersebut dipertegas juga oleh Asosiasi Psikologi Amerika (APA) dalam laporannya berjudul Big World Small Screen: The Role of Television in American Society, tahun 1992, yang menegaskan bahwa tayangan kekerasan berdampak besar pada perilaku agresif anak-anak. George Gerbner dari School of Communication, Universitas Pennsylvania tahun 1996, mengatakan bahwa "Penayangan film kekerasan yang terus-menerus dan berjangka panjang dapat memerparah perasaan kerentanan, ketergantungan dan ketidakpekaan terhadap kekerasan. ${ }^{27}$ Jadi kepekaan mereka terhadap tindakan kekerasan tersebut menjadi tumpul dan mereka menganggap perilaku tersebut sebagai perilaku yang biasa saja.

Dampaknya terhadap kehidupan sosial remaja adalah mereka akan melihat kekerasan sebagai sesuatu yang normal, mereka akan belajar bahwa kekerasan dapat menjadi cara untuk menyelesaikan masalah. Hal ini berhubungan dengan emosi yang dimiliki oleh para remaja. Tingkat emosi remaja yang tidak stabil dapat mendorong para remaja untuk cepat meresponi setiap keadaan dengan cara yang kasar dan mudah bertindak keras.

\footnotetext{
${ }^{24}$ Alvin Toffler, Future Shock (New York: New York Random House, 1984).

${ }^{25}$ E B Surbakti, Awas Tayangan Televisi (Jakarta: Elex Media Komputindo, 2013).

${ }^{26}$ Ibid.

${ }^{27}$ Ibid.
} 


\section{Budaya Kekerasan Ditinjau Dari Perjanjian Lama}

Dasar teologi Perjanjian Lama adalah perjanjian. ${ }^{28}$ Perjanjian bertumpu pada sifat dasar Allah, di mana hukum Taurat menyatakan hubungan perjanjian, dan upacara keagamaan, serta kesalehan bertumbuh bersama-sama dari hubungan perjanjian yang digariskan dalam hukum Taurat. Kesalehan tidak berdiri sendiri, karena kesalehan dinyatakan dalam kehidupan moral masyarakat sebagai sebuah bentuk dari etika. Jadi, kesalehan dan etika berjalan bersamasama. ${ }^{29}$ Apabila dilihat dalam terang Perjanjian Lama, masalah mengenai budaya kekerasan tidak dapat dipisahkan dari kejatuhan manusia ke dalam dosa. Keadaan ini disebabkan karena kekerasan telah menjadi bagian dalam hidup manusia sejak ia menyalahgunakan kebebasannya dan jatuh dalam dosa. ${ }^{30}$ Sejak itulah, kehidupan manusia menjadi bobrok, manusia menjadi egois dan sulit berdamai dengan sesamanya. Kenyataan ini, bersumber dari rusaknya hubungan manusia dengan Allah sehingga hubungan manusia dengan sesamanyapun menjadi rusak. ${ }^{31}$

Sejak manusia jatuh ke dalam dosa, manusia cenderung saling menjatuhkan bahkan merugikan atau menyakiti sesamanya. Sebagaimana yang telah terjadi dalam sejarah perkembangan manusia dalam Perjanjian lama. ${ }^{32}$ Seperti kisah tragis pembunuhan Habel oleh Kain (Kej. 4:1-16), pembalasan dendam Lamekh yang mematikan seorang anak muda (Kej. 4:23-24), musibah air bah dan menara Babel yang membinasakan banyak orang (Kej. 7:10-24, 11:1-9) merupakan derita berdarah dan kehancuran akibat kejahatan dan dosa manusia. Kekerasan pun menambah sejarah umat manusia dalam perkelahian antara para Gembala, Abraham dan Lot (Kej. 3:17), pertempuran antara para raja di lembah Sidim (Kej 14: 1-12), penghinaan Hagar dan penindasan Sara (Kej 16:4-6), kejahatan dan pemusnahan Sodom dan Gomora dan pembutaan orang-orang Sodom (Kej.19:1-29), pemerkosaan Sikhem dan Dina, pembalasan anak-anak Yakub yang membunuh semua laki-laki penduduk Sikhem dan

${ }^{28}$ William Dyrness, Tema-Tema Dalam Teologi Perjanjian Lama (Malang: Gandum Mas, 1990).

${ }^{29}$ Ibid.

${ }^{30}$ Stanislaus, Semerbak Alkitab 3 Mematahkan Siklus Kekerasan.

${ }^{31}$ Hendra Rey, Manusia Dari Penciptaan Sampai Kekekalan: Ilmu Budaya Dasar Dalam Perspektif Kristiani (Malang: Gandum Mas, 2002).

${ }^{32}$ Firman Panjaitan and Marthin S. Lumingkewas, "Keadilan Dalam Hukum Lex Talionis: Tafsir Terhadap Keluaran 21:22-25,” PENGARAH: Jurnal Teologi Kristen 1, no. 2 (2019): 72-73. 
merampas segala harta kekayaan mereka telah memperpanjang sejarah kekerasan berdarah (Kej. 34: 1-31).

Selain itu, kekerasan itu pun melembaga dalam struktur perbudakan dan penindasan sistematis (Kel. 1:8-22). Amos mencela bahwa para pemimpin bangsa menimbun kekerasan dan aniaya di dalam purinya (Am. 3:10) serta mendekatkan pemerintahan kekerasan (Am. 6:3), Mikha mengkritik bahwa orang-orang kaya melakukan banyak kekerasan, penduduknya berkata dusta dan lidah dalam mulut mereka adalah penipu (Mi. 6:2), mereka merobek kulit dari bangsaku dan daging dari tulang-tulangnya dan mencincangnya seperti daging dalam kuali (Mi. 3:1-3). Melakukan kejahatan dan menumpahkan darah orang yang tidak bersalah (Yes. 59:6-7). Nubuat para nabi memaparkan betapa parahnya tindak kejahatan dengan kekerasan (Zef. 3:1-4). Kekerasan dan aniaya terdengar di dalam kota, luka dan pukulan selalu terlihat (Yer. 6:6-7), Yehezkiel menegaskan bahwa negeri itu penuh utang darah dan kekerasan (Yeh. 7:23). ${ }^{33}$

Maka dari itu, Allah memahami bahwa diperlukan sebuah Hukum untuk mengatur kehidupan umat manusia. Sebagaimana telah dinyatakan dalam kehidupan bangsa Israel, terdapat sebuah hukum yang mengatur kehidupan bangsa Israel yaitu Hukum Allah, yang di dalamnya terdapat bentuk hukum moral (Kel. 20:2-17), hukum upacara tentang aturan-aturan kurban yang harus dipersembahkan, kurban pengampunan dosa, hukum hak-hak sipil mengatur tentang ketegangan-ketegangan yang mungkin berkembang pada waktu itu dimana keadilan dan kekudusan dilakukan oleh para hakim dengan didasarkan atas hukum-hukum hak sipil tersebut. ${ }^{34}$ Selain itu, hukum lain yang terkait dengan tindakan kekerasan itu sendiri adalah hukum Lex Talionis yang ditemukan dalam hukum Mosaik Keluaran. ${ }^{35}$ Lex Talionis tertulis di dalam undang-undang Hammurabi. Dalam Undang-undang raja Babel tahun 22852242 SM tertulis:

Jika ada orang membuat mata orang ningrat rusak, mata orang itupun harus dirusakan. Jika membuat tulang rusuk orang ningrat patah, maka tulang rusaknya pun akan dipatahkan. Jika mematahkan gigi orang yang sederajat dengannya, giginya harus dipatahkan, jika merusak gigi orang msikin maka harus membayar sepertiga mina.

Hukum ini membedakan antara golongan ningrat dan miskin, namun intinya jelas bahwa jika ada orang yang merugikan orang lain, kerugian yang

${ }^{33}$ Stanislaus, Semerbak Alkitab 3 Mematahkan Siklus Kekerasan.

${ }^{34}$ Walter C Kaiser, Teologi Perjanjian Lama (Malang: Gandum Mas, 2000).

${ }^{35}$ Jerald F Dirks, Abrahamic Faiths: Titik Temu Dan Titik Seteru Antara Islam, Kristen, Dan Yahudi, Terj (Jakarta: Serambi Ilmu Semesta, 2006). 
sama harus ditanggungkan pada orang itu. ${ }^{36}$ Lex Talionis mengijinkan korban kejahatan untuk mengupayakan pembalasan atau denda yang setimpal terhadap pelaku kejahatan tersebut. ${ }^{37}$ Keberadaan hukum ini penting bagi kehidupan bersama. Karena hukum ini memelihara nilai dan martabat hidup manusia, khususnya terhadap peristiwa pembunuhan yang dilakukan secara tidak sengaja, dengan menempatkannya bersama dengan hukum pembalasan. ${ }^{38}$ Martabat manusia, sebagai makhluk mulia, benar-benar dilindungi melalui hukum ini; karena melalui Lex Talionis hukuman yang dikenakan selalu diukur berdasarkan kelayakan dan bukan berdasarkan keinginan dari kelompok korban. ${ }^{39}$ Jadi hukuman yang diterima oleh pelaku kejahtan selalu setimpal dengan pelanggaran yang dibuat oleh pelanggar hukum. ${ }^{40}$ Hukum Lex Talionis adalah hukum yang mendasari dari setiap pelaksanaan hukum yang disampaikan dalam Keluaran 21:12-36.

Apabila ada orang berkelahi (baik itu dua orang atau lebih) dan kemudian mengenai seorang perempuan yang sedang mengandung dan melukai perempuan itu, bahkan kandungannya, sehingga mengalami luka permanen, maka suami dari perempuan itu berhak memintakan pembalasan yang setimpal/sesuai dengan kerusakan atau kerugian yang dialami, baik oleh pihak suami karena perempuan itu adalah miliknya, maupun dari pihak istri (perempuan itu) sebagai penderita. Akan tetapi jika kecelakaan tersebut mengakibatkan cedera yang lebih berat, maka hukuman yang mengikuti hal tersebut adalah nyawa ganti nyawa, mata ganti mata, gigi ganti gigi, tangan ganti tangan, kaki ganti kaki, luka ganti luka, luka bakar ganti luka bakar (dan) bengkak ganti bengkak.

Secara prinsip, Lex talionis adalah hukum yang menggambarkan tentang upaya pendegradasian seseorang ke tempat yang paling bawah ketika ia melakukan tindakan yang begitu rendah. Maksudnya, ketika seseorang melakukan tindakan pembunuhan, yaitu tindakan yang tidak dapat menghargai kehidupan. Hal itu berarti ia berada dalam titik terendah dalam hidupnya, maka

\footnotetext{
${ }^{36}$ Stanislaus, Semerbak Alkitab 3 Mematahkan Siklus Kekerasan.

${ }^{37}$ Andrew E Hill and John H Walton, Survei Perjanjian Lama (Malang: Gandum Mas, 1996).

${ }^{38}$ Gary Edward Schnittjer, The Torah Story: An Apprenticeship on the Pentateuch (Malang: Gandum Mas, 2015).

${ }^{39}$ Panjaitan and Lumingkewas, "Keadilan Dalam Hukum Lex Talionis: Tafsir Terhadap Keluaran 21:22-25," 78-81.

40 Jan Christian Gertz et al., Purwa Pustaka: Eksplorasi Ke Dalam Kitab-Kitab Perjanjian Lama Dan Deuterokanonika, (Jakarta: BPK Gunung Mulia, 2017).
} 
ia pun akan dikenakan hukuman yang menempatkannya dalam posisi terendah dan hina dalam strata sosial kemasyarakatan. ${ }^{41}$

Prinsip pada hukum Lex Talionis ini berkaitan erat dengan prinsip etika Kristen dimana setiap orang seharunya memberikan penghormatan dan penghargaan terhadap gambar Allah yang terdapat di dalam diri manusia yang diciptakan serupa dan segambar dengan Allah. Gambar Allah merupakan istilah yang dipakai dalam Alkitab sebagai acuan kepada hakikat manusia. ${ }^{42}$

Sebagaimana tertulis didalam Kejadian 1:26 "Allah membuat manusia itu menurut gambar dan rupa-Nya sendiri." Gambar Allah dalam bahasa Ibrani adalah tselem, dan rupa dari kata aslinya demuth, sedangkan dalam bahasa Latin yaitu Imago Dei, yang berarti adanya kesamaan antara Allah dengan manusia. ${ }^{43}$ Kejatuhan manusia dalam dosa tidak membuat gambar Allah hilang dalam diri manusia. Manusia yang telah jatuh ke dalam dosa tetap menyandang gambar Allah. ${ }^{44}$

Dengan pengertian lain, setelah kejatuhan manusia ke dalam dosa manusia masih memiliki gambar Allah, tetapi dosa itu merusak, gambar Allah juga menjadi rusak sehingga manusia tidak dapat lagi mewujudkan kenyataan dirinya sebagai gambar Allah dalam kehidupannya. ${ }^{45}$ Disinilah terletak martabat dan kehormatan manusia yang tidak hilang karena dosa. Oleh karena itu, sekalipun manusia telah jatuh dalam dosa ia tetap menyandang gambar Allah yang harus dihormati, sebagaimana kita menghormati Allah sebagai pencipta manusia. ${ }^{46}$

Kejatuhan manusia ke dalam dosa mengakibatkan permusuhan antara manusia dengan sesamanya. ${ }^{47}$ Akibat yang hebat dari kejatuhan manusia ini dapat dilihat dalam kisah pertama yang diceritakan setelah permulaan dosa, yakni riwayat Kain dan Habel, yaitu riwayat pembunuhan terhadap saudara kandung. Setelah terjadinya peristiwa tersebut, Allah melarang manusia membunuh sesamanya, seperti yang tertulis di dalam Kejadian 9:6, "Siapa yang menumpahkan darah manusia, darahnya akan tertumpah sebab Allah menjadikan manusia itu menurut gambar-Nya sendiri." Pembunuhan dianggap

${ }^{41}$ Schnittjer, The Torah Story: An Apprenticeship on the Pentateuch.

${ }^{42}$ Arie Jan Plaisier, Manusia, Gambar Allah: Terobosan-Terobosan Dalam Bidang Antropologi Kristen (Jakarta: BPK Gunung Mulia, 2000).

${ }^{43}$ Karel Sosipater, Etika Perjanjian Lama (Jakarta: Suara Harapan Bangsa, 2010).

${ }^{44}$ Soedarmo, Ikhtisar Dogmatika (Jakarta: BPK Gunung Mulia, 2009).

${ }^{45}$ Hans Wuysang, "Kekerasan Dan Allah," Jurnal Transformasi: Jurnal Ilmiah Populer untuk Membangun Kepemimpinan Transformasional, 2, no. 1 (2006): 26. Kristen.

${ }^{46}$ Plaisier, Manusia, Gambar Allah: Terobosan-Terobosan Dalam Bidang Antropologi

${ }^{47}$ D F L Bakker, Sejarah Kerajaan Allah 1, (Jakarta: BPK Gunung Mulia, 2016). 
sebagai sebuah kejahatan, karena ketika seseorang membunuh dengan melakukan kekerasan bahkan sampai merenggut nyawa sesamanya, hal itu berarti tidak hanya mengambil hidup orang tersebut, melainkan juga telah "melecehkan gambar diri Allah" yang tercerminkan di dalam diri orang tersebut. Melukai manusia berarti juga melukai gambar Allah sendiri, membunuh manusia yang adalah gambar Allah berarti melakukan pelanggaran terhadap Allah. ${ }^{48}$ Manusia adalah ciptaan dan obyek kasih sayang Allah. Oleh karena itu, seharusnya setiap orang menghormati martabat manusia yang berarti sekaligus menghormati kemahadaulatan Allah. Sebaliknya tidak mungkin menghormati Allah jikalau merendahkan martabat manusia. ${ }^{49}$

\section{Budaya Kekerasan Ditinjau Dari Perjanjian Baru}

Perjanjian Baru menunjukan bahwa hukum Taurat sebagai etika Perjanjian Lama merupakan sebuah dasar bagi etika Perjanjian Baru. Perjanjian Baru hanya membahas mengenai anugerah keselamatan dan tidak membahas mengenai penciptaan dunia dan manusia serta kejatuhannya dalam dosa. Oleh sebab itu, Perjanjian Lama sangat mendasar dan penting untuk etika Perjanjian Baru. Perjanjian Lama maupun Perjanjian Baru, keduanya adalah Perjanjian Allah. Perbedaannya adalah Perjanjian Lama "menubuatkan" kedatangan Mesias sebagai tujuan akhir. Sedangkan Perjanjian Baru mampu "mewujudkan" kedatangan-Nya dan "membuka" pintu Kerajaan Allah bagi manusia melalui karya Yesus. ${ }^{50}$

Yesus Kristus merupakan salah satu tokoh besar yang memberikan pengajaran mengenai etika dalam Perjanjian Baru. Pengajaran-pengajaran-Nya merupakan penyempurnaan dari hukum-hukum dalam Perjanjian Lama yang dirumuskan menjadi hukum kasih. Kasih Allah menjadi inti dari pengajaranNya. Selain Yesus yang menekankan pengajaran-Nya pada kasih, Rasul Paulus pun menekankan hukum kodrati yang bersumber dari pengajaran Yesus yang bertitik tolak pada kasih. Paulus menekankan pengajaran ini dalam suratnya yang pertama kepada jemaat Korintus. Sebagaimana inti dari pengajaran Yesus adalah kasih, demikian pula Rasul Paulus menekankan kasih dalam pengajarannya. Inti pengajaran Paulus terlihat jelas dalam pernyataan ekstrim

${ }^{48}$ Soemitro and Franz Magnis Suseno, Ecce Homo: Seminar Tentang Manusia (Jakarta: Aurora, 1994).

${ }^{49}$ Ibid.

${ }^{50} \mathrm{~J}$ Wesley Brill, Tafsiran Surat Korintus Pertama (Bandung: Yayasan Kalam Hidup, n.d.). 
yang tertulis dalam suratnya 1 Korintus 13:1-13 bahwa karunia-karunia terbesar dan terutama sekalipun tidak akan berguna jika tidak disertai oleh kasih. ${ }^{51}$

\section{Kasih Sebagai Prinsip Etis Yang Utama}

Perintah "jangan membunuh" tidak hanya terdapat di dalam Perjanjian Lama (Kel. 20:3), namun terdapat juga di dalam Perjanjian Baru (Roma 13:9). Tindakan dengan sengaja maupun tidak sengaja mengambil nyawa manusia, bukanlah sebuah tindakan yang penuh kasih, baik dalam Perjanjian Lama maupun Perjanjian Baru.

Dalam Perjanjian Baru, pembunuhan tidak terbatas hanya pada tindakan mengambil nyawa manusia saja. Akan tetapi, pembunuhan juga dapat diartikan sebagai sebuah tindakan yang dilakukan dalam hati manusia. Menurut Tuhan Yesus, pengertian membunuh adalah suatu perwujudan emosi yang jahat, seperti marah yang berakar dalam kebencian (Matius 5:21-22). ${ }^{52}$ Yesus menjelaskan dalam ayat ini bahwa kemarahan yang disebabkan karena kebencian merupakan sebuah tindakan pembunuhan dalam hati, karena itu patut untuk dihukum. Semua hal-hal jahat ini timbul dari dalam dan menajiskan orang (Markus 7:2123). Dalam ayat ini, Yesus mengajarkan bahwa tidak cukup jika seseorang menghindarkan diri dari perbuatan dosa saja, namun yang dikehendaki-Nya ialah setiap orang sama sekali tidak mempunyai keinginan dalam hati untuk melakukan hal-hal yang jahat. ${ }^{53}$

Tindakan pembunuhan yang dilakukan manusia di dalam hati ditegaskan kembali oleh Yohanes dalam 1 Yohanes 3:15 bahwa "Setiap orang yang membenci saudaranya, adalah seorang pembunuh manusia." Begitu pula dengan tindakan kekerasan yang dilakukan oleh setiap orang terhadap siapapun, pada prinsipnya sama dengan pembunuhan yang sama sekali tidak sesuai dengan sifat dan karakter Allah, sebab Allah adalah kasih. ${ }^{54}$

Di dalam Perjanjian Baru juga mengenal Lex Talionis yang ditetapkan untuk mencegah agar manusia tidak hidup sesuai dengan kehendaknya sendiri, main hakim sendiri, bahkan sampai melakukan penumpahan darah karena balas dendam semaunya sendiri. Konsep Lex Talionis ini membatasi balas dendam

${ }^{51}$ Dorothy I. Marx, Itu Kan Boleh? (Bandung: Yayasan Kalam Hidup, 1995).

${ }^{52}$ Josh McDowell dan Norman Geisler, Kasih Itu Selalu Benar: Pembelaan Bagi Satu Kemutlakan Moral: Jawaban Bagi Dilema Etika Atau Situasi Yang Menantang Atau Keputusan Sulit (Jakarta: Profesional Books, 1996).

${ }^{53}$ Arif Wicaksono and Dwi Anggono, "Yesus, Hamba Allah Yang Menderita," FIDEI: Jurnal Teologi Sistematika dan Praktika 2, no. 1 (2019): 153-154.

${ }^{54}$ Surip Stanislaus, Kata-Kata Pedas Bernas (Yogyakarta: Kanisius, 2007). 
hanya pada hukuman yang setimpal, tidak boleh lebih dari yang dilakukannya. Hukum ini sering dimengerti sebagai hukum yang tidak berperikemanusiaan, namun menurut konteks aslinya dimaksudkan untuk mencegah pembalasan, sebagai pedoman para hakim. Akan tetapi, Yesus menolak pendasaran hukum seperti itu, karena meskipun pembalasan dapat dikontrol namun pembalasan sama sekali tidak dapat tempat dalam etika Kristen. Oleh karena itu, Yesus memperkenalkan hukum baru yang tidak didasarkan pada pembalasan tetapi pada kasih kristiani.

Dalam Perjanjian Baru, Yesus menolak menerapkan prinsip etis Lex talionis. ${ }^{55}$ Ia mengajarkan kepada para pengikutnya untuk tidak mendesak hakhaknya di bawah Lex talionis. Akan tetapi Yesus mengajarkan hukum-hukum baru yang diajarkan Yesus yang tertulis di dalam Matius 5:38; Lukas 6:29-31:

Kamu telah mendengar firman, mata ganti mata dan gigi ganti gigi, Tetapi Aku berkata kepadamu: Janganlah kamu melawan orang yang berbuat jahat kepadamu, melainkan siapa pun yang menampar pipi kananmu, berilah juga kepadanya pipi kirimu, dan kepada orang yang hendak mengadukan engkau karena mengingini bajumu, serahkanlah juga jubahmu. Siapa pun yang memaksa engkau berjalan sejauh satu mil, berjalanlah bersama dia sejauh dua mil.

Paulus juga menggemakan hukum baru tersebut dalam suratnya Roma 12:19-2:

Saudara-saudaraku yang kekasih, janganlah kamu sendiri menuntut pembalasan, tetapi berilah tempat kepada murka Allah, sebab ada tertulis: Pembalasan itu adalah hak-Ku. Akulah yang akan menuntut pembalasan, firman Tuhan. Tetapi, jika seterumu lapar, berilah dia makan, jika ia haus, berilah dia minum! Dengan berbuat demikian, kamu menumpukkan bara api di atas kepalanya. Janganlah kamu kalah terhadap kejahatan, tetapi kalahkanlah kejahatan dengan kebaikan.

Melalui hukum-hukum baru tersebut, Yesus mengajarkan agar setiap orang Kristen tidak menuntut hak-hak hukumnya, dan menganggap diri tidak mempunyai hak atas hukum itu, serta lebih mengutamakan kewajiban dan tanggungjawabnya. ${ }^{56}$ Dengan kata lain, hukum baru yang Yesus ajarkan tidaklah bertentangan dengan hukum yang ditulis oleh Musa, melainkan melebihinya. Dalam ajarannya Yesus mencanangkan tatanan baru, yaitu Hukum yang baru yang merupakan Hukum Kasih, dimana setiap umat Kristus yang melaksanakan kasih, mereka juga telah menggenapi tuntutan-tuntutan Hukum

${ }^{55}$ E. Terence, Frethem, Exodes Interpretation: A Bible Commentary for Teaching and Preaching, Ed. James Luther Mays et Al (Louiseville: John Knox, 1991).

${ }^{56}$ Stanislaus, Kata-Kata Pedas Bernas. 
Taurat. Dengan ini maka selaras bahwa kasih adalah kegenapan Hukum Taurat (Roma 13:10). Yesus telah menggenapi Taurat dengan pengorbananNya yang menyempurnakan tuntutan Hukum Taurat, dan memberikan arti yang baru bagi Taurat dalam Hukum kasih. ${ }^{57}$

Kasih kepada Allah merupakan hukum yang terutama dan utama, kasih kepada Allah ini merupakan dasar kehidupan manusia, sehingga kasih kepada sesama harus berdasarkan kasih kepada Allah. ${ }^{58}$ Berhubungan dengan masalah kekerasan yang terjadi dalam kehidupan manusia, Yesus masuk dalam siklus kekerasan, untuk mematahkan kekerasan dan menawarkan jalan keluar.

Dalam kematianNya, Yesus masuk ke dalam siklus kekerasan itu dan melumpuhkan kuasanya. Yesus tidak membalas kekerasan dengan kekerasan yang dapat menimbulkan kekerasan yang jauh lebih besar. Yesus menghadapi kekerasan dengan kasih. KebangkitanNya adalah karena kasih yang memberikan kehidupan dan kemenangan. Siklus kekerasan dan kematian telah dikalahkan, sehingga setelah kematian datanglah kehidupan. Kebangkitan telah menyatakan bahwa kekerasan dan kematian bukanlah akhir segalanya. Kebangkitan menyatakan kuasa Allah dan kasihNya. ${ }^{59}$

Menghadapi kekerasan dengan kasih seperti yang Yesus lakukan seharusnya menjadi prinsip etis yang utama dan menjadi model bagi para semua pengikut Yesus. Ditinjau dari sisi kodratnya, manusia tidak mengenal kasih kepada sesama manusia. Karl Barth mengemukakan pendapatnya bahwa menurut kodratnya manusia hanya memiliki rasa kekeluargaan, kebangsaan, kesadaran akan kepentingan golongan, tetapi sebenarnya tidak mempunyai kasih kepada sesama manusia atau dengan kata lain tidak memiliki rasa kemanusiaan. Hal ini dikarenakan manusia telah kehilangan kemanusiaannya, sehingga Allah harus turun menjadi manusia. Di dalam Yesus Kristus, Allah telah menyatakan apa perikemanusiaan tersebut. Maka dari itu, hanya di dalam Yesuslah manusia baru dapat mengasihi sesamanya. ${ }^{60}$

Kasih orang Kristen selalu sebagai tanggapan kasih kepada Allah. "Jikalau Allah sedemikian mengasihi kita, maka kita juga harus saling mengasihi." (1 Yoh 4:11). Yesus berkata "Inilah perintahKu, yaitu supaya kamu saling mengasihi, seperti Aku telah mengasihi kamu" (Yoh 15:12 dan Yoh 13:34).

57 John S Feinberg, Masih Relevankah Perjanjian Lama Di Era Perjanjian Baru (Malang: Gandum Mas, 2003).

${ }^{58}$ Malcolm Brownlee, Tugas Manusia Dalam Dunia Milik Tuhan (Jakarta: BPK Gunung Mulia, 2004).

${ }^{59}$ Stanislaus, Kata-Kata Pedas Bernas.

${ }^{60}$ Johannes Verkuyl, Etika Kristen: Bagian Umum (Jakarta: BPK Gunung Mulia, 1960). 
Immanuel Kant, seorang ahli filsafat mengatakan bahwa "kasih kepada Allah terdapat di dalam kasih kepada sesama." ${ }^{61}$ Kasih kepada Allah dinyatakan dalam kasih kepada sesama manusia (1 Yoh 4:19-21; 1 Yoh 5:1-3). Kasih Allah di dalam kita membangunkan kasih dalam hati kita kepada sesama. ${ }^{62}$ Kehidupan orang Kristen harus dimotivasi dengan kasih. Kehendak Allah dalam kehidupan setiap orang percaya adalah mengasihi sesama seperti diri sendiri (Mrk. 12:31) sehingga kasih kepada sesama menjadi bukti bagi ketulusan kasih kepada Allah (1Yoh 4:7-8, 20) ${ }^{63}$ Sebagaimana kasih kepada Allah didasarkan atas kasih Allah kepada kita, demikian pula kasih kita kepada sesama manusia didasarkan atas kasih Allah kepada sesama manusia.

Kasih akan Allah tidak dapat dipisahkan dari kasih akan sesama. Orang yang mengaku mengasihi Allah, namun tidak dapat mengasihi sesamanya maka, ia dikatakan sebagai pendusta. Karena seseorang yang tidak dapat mengasihi sesamanya yang terlihat, tidak akan mungkin dapat mengasihi Allah yang tidak kelihatan (1Yohanes 4:20). Pernyataan tersebut menunjukan bahwa kekerasan terjadi sebagai suatu bentuk kegagalan seseorang dalam mengasihi Allah yang juga mengakibatkan kegagalan seseorang mengasihi sesamanya.

Berdasarkan laporan hak asasi manusia di Indonesia tahun 2012 oleh Lembaga Studi dan Advokasi Masyarakat (Elsam), terjadi peningkatan kekerasan dan pengabaian hak asasi manusia. ${ }^{64}$ Data tersebut menunjukan, semakin tinggi tingkat kekerasan yang terjadi karena pengaruh media elektronik yang mengandung unsur kekerasan. Kekerasan masih sering terjadi antar sesama manusia karena pengaruh media yang menyajikan banyak tayangan, game, musik yang mengandung usnur kekerasan. Setiap orang yang dapat dipengaruhi oleh media yang mengandung unsur kekerasan ini, menunjukan bahwa orang tersebut tidak hidup dalam kasih Allah.

Selain itu, prinsip etis lainnya adalah pengendalian diri yang memiliki arti sebagai kemampuan seseorang untuk mengatur tingkah lakunya sendiri, saat ia dihadapkan dengan godaan, gangguan yang berat atau tekanan lingkungan tanpa adanya dukungan. ${ }^{65}$ Robert Anthony mengatakan bahwa "Satu-satunya orang

${ }^{61}$ Ibid.

${ }^{62}$ Malcolm Brownlee, Pengambilan Keputusan Etis Dan Faktor-Faktor Di Dalamnya (Jakarta: BPK Gunung Mulia, 1987).

${ }^{63}$ Karl Heinz Peschke SVD, Etika Kristiani Jilid III Kewajiban Moral Dalam Hidup Pribadi (Maumere: Ledalero, 2003).

${ }^{64}$ Tim Elsam, "Laporan Situasi HAM Di Indonesia Tahun 2012: Tahun Peningkatan Kekerasan Dan Pengabaian Hak Asasi Manusia - E L S A M.”

${ }^{65}$ Surbakti, Awas Tayangan Televisi. 
yang menguasai diri anda adalah diri anda sendiri." ${ }^{66}$ Meskipun sulit, pengendalian diri seharusnya tetap menjadi sikap yang selalu tampak dalam diri setiap orang percaya.

Pengendalian diri berasal dari bahasa Yunani dengan kata enkrateia atau enkrates yang berarti memiliki kuasa untuk mengatasi diri sendiri (self resistant) dan kemampuan untuk mengendalikannya (self continence). Pengendalian diri termasuk buah Roh penguasaan diri yang tertulis di Galatia 5:22;23. Perkara tersebut berasal dari suatu konflik yang dialami manusia diluar dirinya, yang kemudian dikelola dalam hati dan pikiran dan memunculkan suatu respon atau ekspresi emosi tertentu. Hasil dari konflik dalam diri inilah yang harus dikendalikan dengan baik, jika tidak maka emosi ini akan menguasai diri dan dapat memunculkan sikap yang destruktif. ${ }^{67}$ Seperti contohnya marah yang tidak tersalurkan menimbulkan kemarahan pada diri sendiri dalam bentuk depresi atau kemarahan pada orang lain dalam bentuk tindakan kekerasan. Dalam keadaan marah, manusia sulit untuk mengendalikan emosi dalam dirinya. Keadaan ini, menunjukan bahwa manusia cenderung memproyeksikan semua yang jahat kepada orang lain yang dianggap menjadi "musuhnya." 68 Kemarahan yang tidak terkendali seperti ini, dapat mengakibatkan kekerasan dan pembunuhan terjadi. Oleh karena itu, setiap orang percaya seharusnya memberikan dirinya untuk dipimpin dan dikuasai oleh Roh Kudus yang dapat memberikan kemampuan mengendalikan diri manusia. (2 Tim 1:7 dan 2 Pet 2:9).

Media elektronik yang menyajikan film, game, musik yang mengandung unsur kekerasan telah berhasil menjadi alat yang dapat memengaruhi perasaan moral manusia menjadi rusak. Kondisi ini disebabkan oleh keinginan daging dalam diri manusia telah menguasai pikiran serta tindakan manusia (Ef 4:19 dan Gal 6:7-8), sehingga pada akhirnya mengakibatkan manusia mudah melakukan tindak kekerasan dalam dunia nyata.

\section{Implikasi Praktis}

Beberapa impikasi praktis yang dapat diberikan dalam penelitian ini. Pertama, orangtua harus membangun hubungan pribadi dengan anak-anaknya dengan cara meluangkan waktu bersama anak-anaknya untuk menonton tayangan televisi. Kegiatan ini penting dilakukan agar orangtua dapat

\footnotetext{
${ }^{66}$ Antonius Atoshoki, Relasi Dengan Tuhan (Jakarta: Elex Media Komputindo, 2006).

${ }^{67}$ Herbert Miles, Sebelum Menikah, Pahamilah Dulu Seks (Jakarta: BPK Gunung Mulia, 2001).

${ }^{68}$ Brotosudarmo, Etika Kristen Untuk Perguruan Tinggi.
} 
mengarahkan anak untuk menonton tayangan-tayangan yang tidak mengandung unsur kekerasan. Kedua, orangtua memainkan peranan penting dalam memengaruhi anak-anak. Orangtua harus memegang kendali kegiatan menonton televisi anak-anak. Orangtua harus mengontrol dan menentukan programprogram TV yang boleh dan tidak boleh ditonton, begitu juga sama halnya dengan games dan bermacam-macam genre musik yang mengandung unsur kekerasan. Ketiga, Gereja dapat mengadakan seminar khusus yang ditujukan kepada orangtua mengenai budaya kekerasan yang sedang menyerang kalangan anak-anak, remaja pada umumnya. Keempat, Gereja dapat memberikan pengarahan kepada Guru-guru Sekolah Minggu mengenai bahaya media yang mengandung unsur kekerasan dan dampaknya terhadap perkembangan intelektual, kejiwaan, dan moral manusia, serta memengaruhi kehidupan sosial baik anak, remaja, maupun dewasa.

\section{Simpulan}

Media elektronik yang mengandung unsur kekerasan dalam bentuk apapun telah menjadi salah satu alat yang dapat membuat semakin bertambahnya intensitas kekerasan yang terjadi dalam kehidupan manusia. Kondisi ini mengakibatkan kekerasan membentuk menjadi sebuah budaya yang berkembang dan tidak dapat dipisahkan dari kehidupan manusia. Menyikapi permasalahan tersebut, prinsip-prinsip etika Kristen diperlukan untuk dapat menjadi pedoman etis bagi kehidupan manusia secara khusus bagi setiap orang yang telah terpapar tayangan-tayangan kekerasan melalui media elektronik. Prinsip-prinsip etika Kristen telah terangkum di dalam Perjanjian Baru yang menyatakan kasih sebagai prinsip etis yang terutama dalam setiap masalah etis yang di hadapi. Masalah kekerasan dan masalah relasi tidak akan muncul jika manusia menjadikan prinsip kasih ini sebagai nilai tertinggi dalam kehidupannya. Oleh karena itu, penting bagi setiap orang untuk mengembangkan sikap-sikap moral dalam kehidupannya. Sikap-sikap moral tersebut antara lain ialah prinsip menghargai manusia sebagai ciptaan Allah yang serupa dan segambar dengan Allah, memiliki kasih terhadap sesama, dan memiliki pengendalian diri dalam segala hal. 


\section{Daftar Pustaka}

Andini, Thathit Manon. "Identifikasi Kejadian Kekerasan Pada Anak Di Kota Malang.” Jurnal Perempuan dan Anak 2, no. 1 (April 2019): 13-28.

Atoshoki, Antonius. Relasi Dengan Tuhan. Jakarta: Elex Media Komputindo, 2006.

Bakker, D F L. Sejarah Kerajaan Allah 1. . Jakarta: BPK Gunung Mulia, 2016. Batmomolin, Lukas, and Fransisca Hermawan. Budaya Media: Bagaimana Pesona Media Elektronik Memperdaya Anda. Flores: Nusa Indah, 2003.

Brill, J Wesley. Tafsiran Surat Korintus Pertama. Bandung: Yayasan Kalam Hidup, n.d.

Brotosudarmo, R M Drie S. Etika Kristen Untuk Perguruan Tinggi. Yogyakarta: ANDI, 2007.

Brownlee, Malcolm. Pengambilan Keputusan Etis Dan Faktor-Faktor Di Dalamnya. Jakarta: BPK Gunung Mulia, 1987.

_. Tugas Manusia Dalam Dunia Milik Tuhan. Jakarta: BPK Gunung Mulia, 2004.

Bryant, Jennings, and Dolf Zillmann. "Effect of Intensification of Annoyance through Unrelated Residual Excitation on Substantially Delayed Hostile Behavior." Journal of Experimental Social Psychology 15, no. 5 (1979): 470.

Dirks, Jerald F. Abrahamic Faiths: Titik Temu Dan Titik Seteru Antara Islam, Kristen, Dan Yahudi, Terj. Jakarta: Serambi Ilmu Semesta, 2006.

Dyrness, William. Tema-Tema Dalam Teologi Perjanjian Lama. Malang: Gandum Mas, 1990.

Feinberg, John S. Masih Relevankah Perjanjian Lama Di Era Perjanjian Baru. Malang: Gandum Mas, 2003.

Gertz, Jan Christian, Angelika Berlejung, Konrad Schmid, and Markus Witte. Purwa Pustaka: Eksplorasi Ke Dalam Kitab-Kitab Perjanjian Lama Dan Deuterokanonika. . Jakarta: BPK Gunung Mulia, 2017.

Harsanto, Prayanto Widyo. "Metamorfosis Kebudayaan (Sebuah Tinjauan Media Televisi Dan Budaya Kekerasan)." Nirmana 11, no. 1 (2009): 11-18. Hill, Andrew E, and John H Walton. Survei Perjanjian Lama. Malang: Gandum Mas, 1996.

Huesmann, L Rowell, and Lucyna Kirwil. Why Observing Violence Increases the Risk of Violent Behavior by the Observer. Cambridge: Cambridge University Press, 2007.

Ida Ayu Made Gayatri. "Kekerasan Dan Budaya Kekerasan."

Ira Oemar. "Anak SD Melakukan Pembunuhan Berencana Terhadap Temannya - Kompasiana.Com."

Josh McDowell dan Norman Geisler. Kasih Itu Selalu Benar: Pembelaan Bagi Satu Kemutlakan Moral: Jawaban Bagi Dilema Etika Atau Situasi Yang Menantang Atau Keputusan Sulit. Jakarta: Profesional Books, 1996. 
Kaiser, Walter C. Teologi Perjanjian Lama. Malang: Gandum Mas, 2000.

Kistanto, Nurdien Harry. "Tentang Konsep Kebudayaan.” Sabda: Jurnal Kajian Kebudayaan 10, no. 2 (2015).

Liliweri, Alo. Makna Komunikasi Dalam Komunikasi Antarbudaya. Yogyakarta:

PT. LKiS Pelangi Aksara, 2007.

Lismanda, Yorita Febry, Mutiara Sari Dewi, and Ika Anggraheni. "Media

Elektronik Dan Pengawasan Orang Tua Sebagai Pendidikan Anti

Kekerasan AUD Dalam Perspektif Psikologi." SELING: Jurnal Program Studi PGRA 1, no. 2 (2015): 110.

Mander, Jerry. Four Arguments for the Elimination of Television. New York: Quill New York, 1997.

Marx, Dorothy I. Itu Kan Boleh? Bandung: Yayasan Kalam Hidup, 1995.

Miles, Herbert. Sebelum Menikah, Pahamilah Dulu Seks. Jakarta: BPK Gunung Mulia, 2001.

Panjaitan, Firman. "Kekerasan Terhadap Istri Dalam Lingkup Domestik

(Suatu Tinjauan Etis Kristiani Tentang Kekerasan Terhadap Istri)." FIDEI:

Jurnal Teologi Sistematika dan Praktika 1, no. 1 (2018): 42-67.

Panjaitan, Firman, and Marthin S. Lumingkewas. "Keadilan Dalam Hukum Lex

Talionis: Tafsir Terhadap Keluaran 21:22-25." PENGARAH: Jurnal

$\begin{array}{llllll}\text { Teologi Kristen } 1, \quad \text { no. } & 2 & \text { (2019): }\end{array}$

https://doi.org/10.36270/pengarah.v1i2.13.

Plaisier, Arie Jan. Manusia, Gambar Allah: Terobosan-Terobosan Dalam Bidang Antropologi Kristen. Jakarta: BPK Gunung Mulia, 2000.

Rey, Hendra. Manusia Dari Penciptaan Sampai Kekekalan: Ilmu Budaya Dasar Dalam Perspektif Kristiani. Malang: Gandum Mas, 2002.

Schnittjer, Gary Edward. The Torah Story: An Apprenticeship on the Pentateuch. Malang: Gandum Mas, 2015.

Scholastica Gerintya. "73,7 Persen Anak Indonesia Mengalami Kekerasan Di Rumahnya Sendiri - Tirto.ID."

Siburian, Hendro Hariyanto, and Arif Wicaksono. "Makna Belajar Dalam Perjanjian Lama Dan Implementasinya Bagi PAK Masa Kini." FIDEI: Jurnal Teologi Sistematika dan Praktika 2, no. 2 (2019): 207-226. https://doi.org/10.34081/fidei.v2i2.75.

Soedarmo. Ikhtisar Dogmatika. Jakarta: BPK Gunung Mulia, 2009.

Soemitro, and Franz Magnis Suseno. Ecce Homo: Seminar Tentang Manusia. Jakarta: Aurora, 1994.

Solahuddin, S H. Kitab Undang-Undang Hukum Pidana, Acara Pidana, Dan Perdata. Jakarta: Visi Media, 2008.

Sosipater, Karel. Etika Perjanjian Lama. Jakarta: Suara Harapan Bangsa, 2010.

Stanislaus, Surip. Kata-Kata Pedas Bernas. Yogyakarta: Kanisius, 2007. - Semerbak Alkitab 3 Mematahkan Siklus Kekerasan. Yogyakarta: Kanisius, 2007. 
Stevanus, Kalis. "Tujuh Kebajikan Utama Untuk Membangun Karakter Kristiani Anak." BIA': Jurnal Teologi dan Pendidikan Kristen Kontekstual 1, no. 1 (June 2018): 80.

Subagyo, Andreas B. Kualitatif: Termasuk Riset Teologi Dan Keagamaan. Bandung: Yayasan Kalam Hidup, 2004.

Sudarminta, J. Etika Umum: Kajian Tentang Beberapa Masalah Pokok Dan Teori Etika Normatif. Yogyakarta: Kanisius, 2013.

Surbakti, E B. Awas Tayangan Televisi. Jakarta: Elex Media Komputindo, 2013. SVD, Karl Heinz Peschke. Etika Kristiani Jilid III Kewajiban Moral Dalam Hidup Pribadi. Maumere: Ledalero, 2003.

Terence, E. Frethem, Exodes Interpretation: A Bible Commentary for Teaching and Preaching, Ed. James Luther Mays et Al. Louiseville: John Knox, 1991.

Tim Elsam. "Laporan Situasi HAM Di Indonesia Tahun 2012: Tahun Peningkatan Kekerasan Dan Pengabaian Hak Asasi Manusia - E L S A M."

Toffler, Alvin. Future Shock. New York: New York Random House, 1984.

Verkuyl, Johannes. Etika Kristen: Bagian Umum. Jakarta: BPK Gunung Mulia, 1960.

Wade, Carole, and Carol Tavris. Psikologi. Jakarta: Erlangga, 2007.

Wicaksono, Arif, and Dwi Anggono. "Yesus, Hamba Allah Yang Menderita." FIDEI: Jurnal Teologi Sistematika dan Praktika 2, no. 1 (2019): 145-161.

Wuysang, Hans. "Kekerasan Dan Allah.” Jurnal Transformasi: Jurnal Ilmiah Populer untuk Membangun Kepemimpinan Transformasional, 2, no. 1 (2006): 26. 